\title{
CHARACTERISTICS PROTECTION OF MADURA TOBACCO THROUGH THE GEOGRAPHICAL INDICATIONS REGIME ${ }^{\Omega}$
}

\author{
Djulaeka and Makhmud Zulkifli \\ Trunojoyo Madura University \\ E-mail: djulaeka@gmail.com and mzutm@yahoo.com
}

\begin{abstract}
Madura Tobacco has typical characteristics which are grow in the area of Madura, especially in Pamekasan and Sumenep area. The different specificity of the Madura tobacco with tobacco in other regions makes tobacco has the potential to get the protection of geographical indications as one of the intellectual property rights regime. Issues of the research focused on the importance of geographical indications for typical regional products, local institutional role in protecting regional superior products and local institutional constraints that exist in Pamekasan and Sumenep area as legal standing in an effort to protect the tobacco through the regime of geographical indications. This study is an empirical research with qualitative approach and research located in Madura, especially in Pamekasan and Sumenep area. The results showed that geographical indications can provide local products a protection, local agencies in the area of research references tend to be dormant and do not understand the potential protection of geographical indications for tobacco. Political will of the Local Government is the key word in the protection of geographical indications based on regional products.
\end{abstract}

Key words: geographical indications, legal standing, madura tobacco.

\begin{abstract}
Abstrak
Tembakau Madura memiliki karakteristik khas yang tumbuh di wilayah Madura, khususnya Kabupaten Pamekasan dan Sumenep. Kekhasan tembakau Madura yang berbeda dengan tembakau di wilayah/daerah lainnya memberikan pertimbangan bahwa tembakau berpotensi untuk memperoleh perlindungan indikasi geografis sebagai salah satu rezim hak kekayaan Intelektual. Isu penelitian difokuskan pada arti penting indikasi geografis bagi produk khas daerah, peran kelembagaan lokal dalam melindungi produk unggulan daerah serta kendala kelembagaan lokal yang ada di daerah Kabupaten Pamekasan dan Sumenep sebagai legal standing dalam upaya melindungi tembakau melalui rezim indikasi geografis. Penelitian ini merupakan penelitian empiris dengan pendekatan secara kualitatif dan lokasi penelitian di wilayah Madura, khususnya Kabupaten Pamekasan dan Sumenep. Hasil penelitian menunjukan bahwa indikasi geografis dapat memberikan perlindungan produk lokal daerah, lembaga lokal di wilayah rujukan penelitian cenderung mati suri dan tidak memahami adanya potensi perlindungan indikasi geografis untuk tembakau. Political will Pemerintah Daerah merupakan kata kunci dalam perlindungan produk daerah berbasis indikasi geografis.
\end{abstract}

Kata kunci: indikasi geografis, legal standing, tembakau madura.

\section{Introduction}

Indonesia as the developing country can be considered as a state that recognizes the existence of geographical indications as part of the rights of intellectual property although not all regional give serious attention to the regional product protection which have the poten-

$\Omega \quad$ This article was part of a research funded by DIKTI on TA. 2014-2015 Based On The Letter of A Fundamental Research Implementation Agreement Year 2014 UTM TA 2014 No. 232.53/UN46.2/LT/2014, 09 ${ }^{\text {th }}$ May 2014. tial geographical indication. In nowadays, products that already have successfully obtained the protection certificate of geographical indications is still limited to thirty-one products in several areas, there are: Arabica Kintamani Coffee, Arabica Gayo Coffee, Jepara Carving, Muntok White Pepper, Tobacco Mole, Adan Krayan Rice, Kale Lombok, Sumbawa Horse Milk and Sumbawa Honey. Compared with other fields of intellectual property rights the geographi- 
cal indications protection can introduce a superior product, improving the economy of the region, as well as prosper people in the region. This is in line with the phrase of William van Caenegem that, "Gls as a tool of economic development to benefit indigenous groups". ${ }^{1}$

Law No. 15 of 2001 on Trademarks (hereinafter referred to the Trademark Law of 2001) and Government Regulation No. 51 of 2007 on Geographical Indications (hereinafter referred to the PP of Geographical Indications) authorizes the right to the 'institution' in the area as the party that can represent local communities to register a potential superior product protected by geographical indication. Such arrangements have been followed by a Memorandum of Understanding from Ministry of Justice and Human Rights Affairs, Ministry of Home Affairs and Ministry of Agriculture about the "Potential Development of Geographical Indications Products for Agricultural Sector" on April 26, 2011, but it still has not been followed by a strong involvement of the institutions in the region to responds it maximumly. Results of the study conducted by the authors in the area of Bangkalan, one of the Madura mention that there was no attempt to provide protection of superior product due to the un-understood as the maximum number of regulations related to geographical indications, so the local government is still not ready to register a superior product area through the geographical indications protection. ${ }^{2}$ The results also show that in Bangkalan area has many potential products that can be registered as a geographical indication, such as: craft whip, durian, bark, and $b a-$ tik, but all of that are still unregistered as a protected geographical indication products. ${ }^{3}$ The same study conducted by Moh. Fahri, et. al., revealed that in Sumenep area shows that

William Van Caenegem, Jen A. Cleary, and Peter Drahos, "Pride and Profit: Geographical Indications as Regional Development Tools in Australia," Journal of Economic and Social Policy, Vol. 16 | Iss. 1, Art.5 2014, Australia: Southern Cross University, page. 7.

2 Djulaeka, "Perlindungan Indikasi Geografis dan Peran serta Pemerintah Daerah", Jurnal Ilmu Pengetahuan Sosial, Vol. IX Maret 2008, Jember: FKIP-Jember University in collaboration with the Association of Graduate IPS East Java, page 42.

3 Ibid, page 40. the medicinal product has the potential to be registered with geographical indications, and not many people understand where the protection of geographical indications, so the existence of strong institutions are needed as a protection of geographical indications. ${ }^{4}$

Some potential superior of regional product protected by geographical indication in Madura is in the Bangkalan area with excellent products 'bark' which has a distinctive taste and it is different from other regions, as well as the unique Batik of Tanjung Bumi. Sampang regency has advantages for agricultural products which is white 'guava' from Camplong while Pamekasan region has the plantation products such as 'tobacco' plants. Sumenep as the adjacent area to Pamekasan is known with the superior product which is 'chilli herbs'. Sensitizing of governments and communities around is a part of the importance of the protection of geographical indications typical regional products that will be able to improve the welfare of local communities. On the other hand, local institutions in Madura, especially Pamekasan and Sumenep as a 'motor' of legal standing can not perform its function as the mandate contained in the Trademark Law of 2001 and PP of Geographical Indications.

Superior product protection of geographical indications nowadays is a necessity for every region in order to improve the welfare of society and introduction of the regional names. Providing protection of geographical indications to the superior and typical products of the area in addition to introduce the regional names, welfare the community of product producer, are expected to increase the sale value of the product. Thats way it is a challenge for the region in order to prevent the use of names related to specific product areas that are not come from the area concerned by superior products registration with geographical indications. Regions have many role to advance the welfare of

\footnotetext{
4 Moh.Fakhry, et.al, 2007, Permodelan Penyuluhan dalam Rangka Pemberdayaan dan Pelestarian Hak Indikasi Geografis Budaya Tradisional Madura, Reports of Competitive Research Grant. Unpublish. Bangkalan: Trunojoyo University, page 76.
} 
society with the various programs in the name of 'poverty of the poorness. ${ }^{5}$

Protection of the geographical indications tobacco plants from Pamekasan and Sumenep is still constrained by the powerlessness of local institutions that tend torpor. From the description, this study sought to contribute to the area which has a specific product to provide protection through the regime of geographical indications.

\section{Research Problems}

Regarding to the background, this study try to explain: first, the importance of the geographical indications protection for the region; second, the role of local institutions in the geographical indications protection; and third, constraints of local agencies providing protection to the Madura tobacco superior product through geographical indications.

\section{Research Method}

This research is an empirical research that leads to the kind of socio-juridical research (sociolegal research) with a qualitative approach to uncover the facts in depth based on the science characteristics behind the phenomena that occur in the community. Related to this study, the method and the design used is a blend of legal research methods and sociological research methods. Legal perspective appears on the analysis of legislation in the field of intellectual property rights, in particular the Trademark Act and other regulations related to geographical indications. In a sociological perspective, the analysis is directed to the work of the law in society by collecting data through indepth interviews (indept interview) and focus group discussion (FGD) with stakeholders in Pamekasan and Sumenep area.

Informants in this study are the stakeholders as the relevant parties in order to provide legal protection against a superior product based on Geographical Indications, among other

Djulaeka, Yudi Widagdo Harimurti, dan Makhmud Zulkifli, "Tantangan Daerah dalam Upaya Perlindungan Indikasi Geografis", SNaPP2014-Proceedings of the Social, Economic and Humanities, Vol. 4 No.1 October 2014, Bandung: UNISBA, page 261-262. local institutions, both governmental and nongovernmental, local government (including the related agencies), consumers who are care and has taste for products and community groups or associations that facilitate the activities of the cultivation of tobacco plant products as good or excellent in Madura, especially in Pamekasan and Sumenep which are expected to be the legal standing to represent the region to register the tobacco products through the regime of geographical indications.

Data collections are done by: In-depth interviews (indept interview) and Focus group discussions (FGD) with the stakeholders, local agencies, and also government such as related agencies and non-government including farmers' groups or other associations. Field records is required for notice the new things which have connection with a list of questions that had been prepared. Data were analyzed qualitatively, to describe the implications of the enactment of legislation related to geographical indications and constraints in the field concerned have not been the registerated of tobacco products as the leading region through geographical indications, in order to obtain an overview and input as a whole for policy makers or legislators regarding how should a regulatory provisions are made to fit and protect the interests of the community. Schematically, the stages of research is as follows:

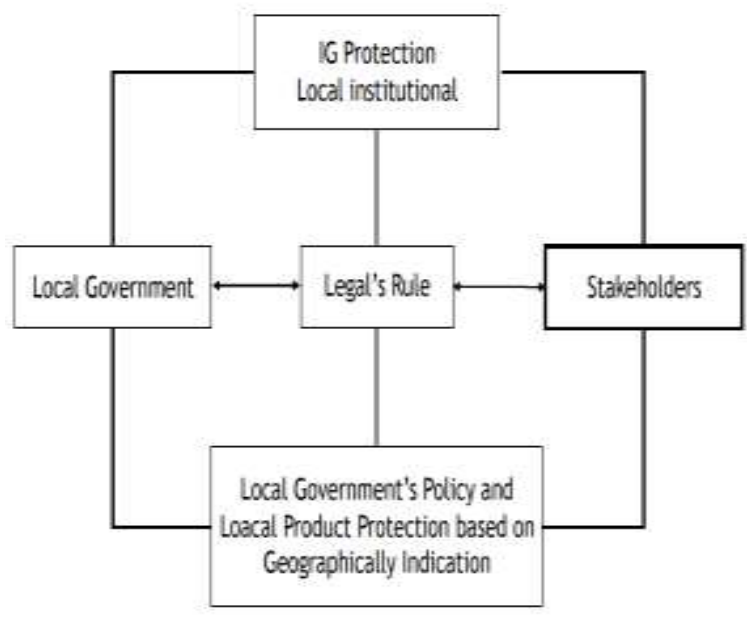

Discussions

The Importance of Geographical Indications Protection for Region 
Geographical indications as provided for in Article 56 (1) Trademark Law of 2001, that "geographical indication is protected as a sign which indicates the place of origin of the goods due to the geographical environment including natural factors, human factors, or a combination of both factors, provide specific characteristics and quality of the goods produced". Implied sense in the context of geographical indications, it should contain the specific aspects of the name where the origin of goods that could be used as part of a sign or distinctive mark. These aspects can be tangible elements of nature or other environments that are unique, that show a special relationship between the goods and the name where it comes from. According to Sarah Bowen "Gls can be viewed as a specific type of quality label". ${ }^{6}$

The existence of a geographical indications substantive requirement, suggesting that local communities have the right of protection against the 'ownership' rights of geographical indication, remember that the existence of elements/geographic factors greatly affect the long journey in carving a reputation for producing goods/products that have a unique characteristics. It contains the philosophy that the protection of geographical indications regime not only introduce the name of the region, or a particular region, but also try to improve the welfare of the local community where the products or goods produced. Caenegem suggestion, that:

"Gls might be a suitable regulatory tool for protecting and promoting the knowledge and interests of Indigenous people. A Gl scheme is also an instrument of rural and remote regulation because it tends to concentrate resources around developing specialisation in the production of a product in a particular region". ${ }^{7}$

The Data come from Cerkia Bramley, et. al., ${ }^{8}$ as a part of the EU Dolphins research pro-

6 Sarah Bowen, "Embedding Local Places in Global Spaces: Geographical Indications as a Territorial Development Strategy", Rural Sociology, Vol. 75 No. 2 June 2010, Columbia: Cornell University, page 222.

7 William van Caenegem, et.al, op.cit., page. 3-4.

8 Cerkia Bramley, Estelle Bienabe, and Johann Kristeen, "The Economics of Geographical Indications: Toward a ject mention that the qualification of a product, can be used as part of a territorial strategy, but its effectiveness is depends on several factors, including actors/local groups that play a role in making decision related to the exclusivity of the qualifying product. The potential for a strong quality of the label led to the development of an area, and the exclusivity affecting an increasing revenues and profits for a group of farmers. On the other hand consumers are protected because there is a guarantee of the quality and the authenticity of a local product. The existence of cases use the name 'Gayo Mountain' by the Holland Coffee Inc. (in the Netherlands) ${ }^{9}$, is actually a valuable lesson of the importance of the role of local authorities, especially local institutions in the protection of geographical indications as regional assets that provide economic value for the region. Marette suggestion, that:

"In the context of Gls, quality attributes of interest to consumers are presumed linked to the specific geographic origin of the good and/or particular production methods used in that region (the notion of "terroir"), and such attributes cannot be determined through inspection by the consumer prior to purchasing the good. ${ }^{10}$ In such a context of GI proliferation, quality management is crucial to establishing a reputation and getting high prices. Given the proliferation of Gls, there is a risk that some may give rise to unsubstantiated claims that do not help consumers clarify their opinions on characteristics of food products. These "poor" Gls may tarnish the credibility of "serious" Gls that employ rigorous certification processes in order to maintain quality". ${ }^{11}$

Conceptual Framework for Geographical Indication Research in Developing Countries", WIPO Research Papers, January 2009, page. 128, in Djulaeka, 2014, Konsep Perlindungan Hak Kekayaan Intelektual (Perspektif Kajian Filosofis HaKI Kolektif-Komunal, Malang: Setara Press, page. 145.

$9 \quad$ Zeynita Gibbons, “Kopi Gayo tidak Lagi Merek Dagang Perusahaan Belanda", 25 Juli 2013, website: www.antaranews.com/, accessed on March 20, 2015.

10 Giancarlo Moschini, Luisa Menapace, and Daniel Pick, "Geographical Indications and The Competitive Provision of Quality in Agricultural Markets", American Journal of Agricultural Economics, Vol. 90 No. 3 August 2008, USA: Agricultural \& Applied Economics Association, page 795

11 Stéphan Marette, "Can Foreign Producers Benefit from Geographical Indications under the New European 
Potential product for geographical indications protected significantly affect the efforts of the parties concerned in the region in making a policies that can improve the awareness of local communities or stakeholders in fulfilling and maintaining the uniqueness and the typical characteristics which is inherent in the local product and it should provide a budgetary allocations as the aid proposal of regional product protection based on geographical indications. Tobacco is one of the flagship products in Madura, especially Pamekasan tobacco which has typical characteristics and a semi-aromatic which is different with the type of tobacco from other areas.

\section{The Role of Local Institutions in the Protec- tion of Geographical Indications}

Favor of the community interests is a part of the concept of 'ownership' 'collectivecommunal' as reflected in Article 56 (2) Trademark Law of 2001 which stated that: "Geographical indications are protected after registered on the basic of the petition filed by: (a) Institution that represents the people in the region that produces the goods, which consists of: first, parties who seek a goods that are the result of nature or natural resources; second, producers of agricultural products; third, author of the crafts goods or industrial products; or fourth, merchants who sell goods; (b) Institutions of a given authority to do so; or a group of that consumer goods. "

The concept of 'institution' in Article 56

(2) Trademark Law of 2001 given the authority to represent the people in the region that produces the goods in the register of potential products based on geographical indications, and can be done by the producers of agricultural products, crafts goods maker or industrial products; or merchant who selling goods, the agency was given authority to do so, or a group of consumer goods. While in the explanation of

Regulation?", Estey Centre Journal of International Law and Trade Policy, Vol. 10 No. 1 2009, Canada: Estey Centre for Law and Economics in International Trade, page 72 . the provisions of Article 56 (2) Trademark Law of 2001, the term 'institution' refers to the institution that is authorized to register the geographical indication and the agency is other government agency or official institutions such as cooperatives, associations and others. Broader interpretation related to 'agencies', contained in the explanation of Article 5 PP on Geographical Indications, that the term of institution authorized for that is the government institution in the area that charge goods submitted to the petition, such as the Local Government both at the provincial and district/City includes cooperatives, associations, or foundations, whose members are local manufacturers. While the presence of government agencies in this context refers to local governments, both at the provincial and district/city, including the relevant agencies with field object that has the potential for protected geographical indications, for example, the Department of Agriculture and Plantations, Mining Office, or other relevant agencies.

The existence of 'agency' as a representative of the region or community is a prerequisite inseparable from efforts to provide adequate protection of geographical indications of an area, so that concern the Local Government and stakeholders is essential. For example Waterford area which has the potential of superior products such as tobacco, the step taken is to form an institution that represents the people of Waterford to form a Geographical Indication Protection Society (MPIG) Tobacco Srinthil Waterford and the institutions represented in the local government and related agencies. Unlike the protection of geographical indications for tobacco Sumedang, which is the regional representative in the formation of MPIG Tobacco Sumedang is the Local Government, the Association of Tobacco Growers and Employers Sumedang Regency.

The success of a region in the protection of geographical indications can not be separated from the good coordination and cooperation between offices/local related SKPD in forming a joint commitment in providing adequate protection to the superior products distincti- 
vely owned area. Or local government agencies/SKPD understand the extent of the protection of geographical indications at the normative level, so there is no initiation of planning for the allocation of the budget related to the protection of geographical indications for the excellent products of tobacco. While the existence of an element of the tobacco farmers as well as businesses in the Pamekasan and Sumenep area is supposed to represent the region, lack of sensitivity to the potential for geographical indications based tobacco caused by several things: ${ }^{12}$ first, do not understand the benefits and the potential for tobacco to be geographical indications registered; second, do not have the knowledge in process of registration of geographical indications; and third, the absence of initiation to approach collectively between the farmer and businessman tobacco in the form MPIG.

Efforts acquisition of protection of geographical indications, basically needed for several reasons, among others: first, an agreement between the producers in determining producer groups producing products that are relevant to the products produced; second, collective agreements between manufacturers in terms of determining the boundaries of the area; third, the agreement in defining the product to be produced; fourth, the agreement in the trade to make the code of conduct, which determines the production process, the resulting product specifications, to avoid fraud among producers; and fifth, the agreement in performing control functions, whether conducted by the agency's internal, or external. The agreement is the result of joint work with other producers agreed to increase the added value of products and lift the name of the region in accordance with the characteristics typical of the region. The main key to success-based protection of geographical indications lies in better coordination between them to produce products that managed to obtain the protection of geographical indications. A geographical indication can have a significant impact on a region's

12 The Result of the Field Study which has decriptively observed. economic performance and cultural heritage because it protects the identity of indigenous products. ${ }^{13}$ The existence and role of local producers in initiated to develop a superior product through the protection of geographical indications, will take effect on economic progress and sustainable rural agricultural areas. In line with research conducted by Bannette Jennifer, that, "...the goals of rural economic development and sustainable agriculture are best accomplished when the $\mathrm{Gl}$ is managed by local producers." 14

Comparative studies conducted by Angela Tregear et al. ${ }^{15}$ mentions the existence of two phases of the process can be carried out by local agencies in an effort to provide protection of geographical indications of success is through tahapaan ex ante and ex post. At the stage of ex ante needed compromise among the producers for the pursuit of quality products according to the standards prescribed so that the leadership factor in the institution established between producers to be important as a balance between producers who are active and which do not actively participate. Being at the stage of ex post (after obtaining the protection of geographical indications) formed institutions can play an active role by leveraging factor of the quality of products as part of a territorial strategy.

Overall indicate showed that the concept of collective agreements that lead to the togetherness factor, togetherness, and kinship are the basis of a community formed or social life that will affect and help the accelerate protection of geographical indications in each region. Rob Edger revealed that:

13 Anson C J, "Geographical Indications: A Marketing Stance", International Journal of Economics, Commerce and Research (IJECR), Vol. 2 Iss. 2 June 2012, USA: Transstellar Journal Publications and Research Consultancy Private Ltd., page. 13.

14 Jennifer Bannette, "Geographical Indication as a Tool to Promote Suistainability? Café de Colombia and Tequila Compared", Ecology Law Quartely, Vol. 39, University of California-Berkeley School of Law, page. 111

15 Angela Tregear, et.al, "Regional foods and rural development: The role of product qualification", Journal of Rural Studies, Vol. 23 2007, United Kingdom: Elsevier Ltd., page. 21. 
"collective rights or group rights, are rights held by group or sets, rather than by individual. A 'group' generally connotes a set of individuals with strong racial, state, religious, or linguistic ties. ${ }^{16} \mathrm{Gl}$ holders may prosecute any other practice liable to mislead the consumer as to the true origin of the product. ${ }^{17}$

This Properties of collective and communal services is the one that distinguishes the regime of geographical indications with the regime of intellectual property rights, such as brands, patents, industrial designs or other regime because basically the regime of geographical indications derived from factors region/ area, all of which affect the characteristics of the products produced by certain regions, the "given" Factor can be regarded as something very hung on the willingness and ability of each region to find the excellence and uniqueness of its products. In some literature on geographical indications, one of that stated that:

"the theoretical associations between GI protection, local environmental resources, and rural livelihoods are mediated through the concept of terroir. The fundamental argument advanced by the notion of terroir is that "the special quality of an agricultural product is determined by the character of the place from which it comes"18

The course of history have noted that not all of countries are agree and gives the protection of regional products through geographical indications, so some developed countries ${ }^{19}$ thought that through collective brand protection is considered enough and are capable of providing protection for the local products. As revealed by Webster D. Mcbride that:

16 Rob Edger, "Collective Rights", Saskatchewan Law Review, Vol 72 2009, Canada: University of Saschatchewan - College of Law, page. 4, in Djulaeka, 2014, op. cit, page. 76.

17 Tim Jay and Madeline Taylor, "A case of champagne: a study of geographical indications", Vol. 29 July 2013, Australia: Faculty of Law- Bond University, page. 11.

18 Sarah Bowen, Ana Valenzuala Zapata, "Geographical Indications, Terroir, And Socioeconomic and Ecological Sustainability: The Case Of Tequila", Journal of Rural Studies, Vol. 25 2009, United Kingdom: Elsevier Ltd., page. 108.

19 Djulaeka, 2014, op.cit, page. 51.
"In contrast, GIs endow collective rights that attach to a geographical region rather than to a particular individual, entity, or group. An agent's right to use a GI, therefore, is not owned and cannot be sold or licensed; any product that meets the qualifications of a particular GI may benefit from its protection. A second contrasting feature of Gls is that they typically protect the "old" as opposed to the "new". A Gl's basis is not an innovative creation but an established practice combined with an established reputation. Third, whereas traditional intellectual property rights are granted to the products of human creativity and industry alone, Gls are granted only when a certain nexus has been established between human craft and a particular geographical location". ${ }^{20}$

\section{Constraints of Local Institutions in the Tobac- co Plantation Protection of Geographical Indi- cations}

Madura region is geographically divided into four Districts which include Bangkalan, Sampang, Pamekasan and Sumenep. As an initial reference mind that a superior product in Bangkalan are salaks as stated in the Decree of the Minister of Agriculture No. 573/Kpts/SR.120 19/2006 on releasing of Salak Kramat Bangkalan as varieties. Considerations which can be observed from the bark of salak Kramat Bangkalan is has the advantage of a higher weight apiece, flesh white to yellow white with a sweet taste masir, part of which can be eaten more, adapting well in the lowlands. The study conducted by researchers and teams in 2012 known that salak Bangkalan has been made into many kinds of food suc as Zalacca palm dates, Zalacca kismis, Zalacca syrup, Zalacca jam, and Zalacca dodol as it is done by the Ambudi Makmur farmer groups. ${ }^{21}$ However, efforts to maintain the distinctive flavor characteristics, salak

20 Webster D. Mcbride, “Gi Joe? Coffee, Location, And Regulatory Accountability", New York University Law Review, Vol. 85: 2138 December 2010, New York: New York University School of Law, page 2145.

21 Mufarrijul Ikhwan, Djulaeka, et.al, "The law setting of Traditional Knowledge (Traditional Knowledge) As Protecting Local Wisdom by Parliament Bangkalan Madura", Journal Yustisia, Ed. 85 January-April, 2013, Surakarta: Faculty of Law, University of March, page 75. 
Kramat still needs to be cultivated, especially in the area of Kramat Village, District Kramat because salak have been recognized as superior varieties.

Unlike the Camplong Water Rose-Apple (Madura Language: Klampok) is one of the local fruit horticultural products derived from Sampang well developed and has a sweet taste, crisp and fresh if they are grown and harvested in they central area in District Camplong. Through the Minister of Agriculture Decree No. 40/KPTS/TP.290/1997 Camplong Water RoseApple has been released by the Ministry of Agriculture as One of Superior National Varietes. However, just as salak Kramat is still not getting attention for protected geographical indications.

Research in this article focused on Pamekasan and Sumenep regency which has the same advantages, namely tobacco products. Early research which facilitated by Plantation Office of East Java Province showed that tobacco as a product that has the unique characteristics based on geographical indications. Results of the study there are plant index test 22 (twenty two) tobacco varieties Madura, shows that there are three (3) varieties that have a high index of plants namely Tumpang Jasmine (62.86), Prancak-95 (53.2) and Jepon Kenik (58.3). ${ }^{22}$ It is further mentioned that the index level of tobacco plants is strongly influenced by environmental factors and interactions between genotypes (varieties) and the environment. ${ }^{23}$

Both of these regions have the same area for superior varieties of tobacco (Madura), known as Prancak-95. This variety is obtained from a selection of local varieties originating from Prancak, District Pasongsongan, and Sumenep. Prancak-95 varieties released by the Ministry of Agriculture of 1997 by Decree No. 731/Kpts/TP.240/7/97. Madura tobacco varieties Prancak has a fragrant aroma and savory, and suitable for ingredients of horse-drawn cart

22 Mahfud Efendy, et.al, 2013, the Land Suitability Mapping Activity Area of Tobacco Crop Regions in Pamekasan, Research Report, Unpublish, Bangkalan: Faculty of Agriculture, Trunojoyo University and BAPPEDA Pamekasan, page 118

23 Ibid, page 120 cigarette. This variety is more suitable for dry land, in the mountains and fields. In efforts to provide protection of tobacco plants as superior varieties in Pamekasan, local governments have settle in Regulation Pamekasan No. 3 of 2002 on Quality Control and Protection of Authenticity Madura Tobacco followed by Regulation Pamekasan No. 6 of 2008 on the administration of Tobacco with the aim of providing welfare for farmers

Related to the situation of farmers in the institutional, the collaboration of research between the Faculty of Agriculture, University Trunojoyo and Bappeda Pamekasan states that "84\% of tobacco farmers in Pamekasan have the perception that the government's role against tobacco farmers is nothing, $14 \%$ do not know anything, and $2 \%$ out mainly in the handling of direct cash assistance (BLT), but does not know its use for other beside for consumption. ${ }^{24}$ Findings from the other studies mention that tobacco farmers are still far short of expectations for welfare due to poor knowledge on tobacco that does not have a bargaining position with industry and there is no policy standardization of quality tobacco. ${ }^{25}$ Potential of tobacco to obtain the protection of geographical indications is already done by the assessments of the Plantation Office of East Java Province in depth through research with related agencies in the area of Pamekasan and Sumenep as a condition for substantive compliance with the Book of Requirements of Geographical Indications as a document containing information on the quality and characteristics of goods which can be used to distinguish the goods of one another that has the same category, which follows contain as settles in Article 6 paragraph (3) PP Geographical Indications.

Tobacco plants were identified as a superior product based on geographical indications is still in the process of establishing local agen-

24 Faculty of Agriculture University of Trunjoyo MaduraBappeda Pamekasan, op.cit, page. 137.

25 Tataq Handaka and Surokim, "Communication Pattern of Tobacco Farmers Group Madura as the Basis of Forming Empowerment Economic and Political Policy", Journal of Karsa, Vol. 23 No. 2 December 2014, Pamekasan: STAIN Pamekasan, page 238. 
cies as legal standing and through the Forum Group Discussion (FGD) farmer groups/Tobacco Farmers Association (APTI) Sumenep as one of the backbone has an agreement to form community groups protection indication Geographical tobacco, although substantively institutions still constrained by several factors, which are: ${ }^{26}$ first, limitations in understanding the Trademark Government Regulation 2001 and Geographical Indications; second, awareness of the importance of the protection of Geographical Indications is not maximized; third, the absence of participation of stakeholders in the region; fourth, local agencies in the area tend to be dormant and as one example of a local institution that tends to 'dormant' contained in the poktan institution caused by several things, there are: the entrepreneurial spirit is low, the availability of capital is inadequate, moral hazard, and weak institutional support agriculture itself; ${ }^{27}$ fifth, lack of coordination among institutions in the region; and sixth, the existence of a third party as the liaison between farmers and buyers very dominar in pricing, particularly tobacco in the Pamekasan and Sumenep great influence on the efforts and the formation of 'local institutions' as 'legal standing', so that the tendency of farmers are reluctant to maintain and keep grade/quality of the tobacco plant.

It needs precision and the 'political will of local government in making policy, deciding and allocating budgets to provide protection product duly potential areas of geographical indications through planning and its activities which refers to the acceleration-based protection of geographical indications. Currently the relevant authorities, particularly the Plantation Office of East Java province has been trying to give attention to the Madura region through policies on an ongoing basis to provide and register the product, seeded in every area of the city/county. Interviews and discussions with the

26 The results of studies that have been processed descriptively.

27 Bondan Satriawan and Henny Oktavianti, "Poverty Alleviation Efforts At Farmers Using Collective Actions Institutional Model of Agriculture", Journal of Development Economics, Vol. 13 No. June 1, 2012, Surakarta: Surakarta Muhammadiyah University, page 102.
Plantation Office of East Java Province states that "attainment targets tobacco as a geographic indication protection should be implemented lately on 2016". 28

Results of other studies provide recommendations for local governments is a program of creation of markets for farmers, program formation/activation KUT/Gapoktan, mentoring programs KUT/Gapoktan, as well as the procurement program demonstration plots in each village $^{29}$ as a one of the options for increasing farmers' income and sustainability of product protection areas potentially superior geographical indication. As an expression of Sarah Bowen and Zapata that "GI supply chains, the presservation of the link to terroir is both a critical strategy for local actors and a guarantee of the diversity and specificity of the product. Terroir represents a discursive tool". 30

\section{Closing \\ Conclusion}

Based on the analysis conducted, it can be concluded that: first, geographical indications are important in providing protection unique regional products that have special characteristics related to the influence of geographical elements either due to environmental factors as well as people who live in an area. Products that protected by geographical indication will give effect to the added of value or sale value of the product; second, a local institution in the region Pamekasan and Sumenep haven't act well as the mandate of the Trademark Law Th. 2001 or PP Geographical Indications, due to local institutions both elements of the Local Government or related agencies/SKPD in that area understanding of the protection of geographical indications limited to the normative level, so there is no initiation of planning for the allocation of the budget related to the protection of geographical indications for the excellent products of tobacco, while the component and

28 Interview with Ms. Ambar Purwati, Kasi Rempah and Spreader of Official Plantation East Java Province, March 23 $3^{\text {rd }}, 2015$.

29 Bondan Satriawan and Henny Oktavianti, op.cit, page 110.

30 Sarah Bowen, Ana Valenzuela Zapata, op.cit, page 118. 
businessman tobacco farmers do not understand the benefits and the potential for tobacco to be registered on geographical indications, the lack of the knowledge in process of registration of geographical indications and the lack of initiation to approach collectively between the farmer and businessman tobacco in to form MPIG.

Third, constraints that faced by the local agencies in the protection of geographical indications, which are: limitation in understanding the Trademark Law 2001 and PP Geographical Indications, awareness of the importance of the protection of Geographical Indications is not maximized, the absence of participation of stakeholders in the region, local agencies in the area tend to dormant, lack of coordination among institutions in the region, where a third party is dominant so that the tendency of farmers are both producers tobacco reluctant to maintain and protect the grade/quality of the tobacco.

\section{Suggestion}

According the above discussion and conclusion it can be suggested in the future in an effort to protection Madura tobacco are: first, the socialization related to the importance of the protection of geographical indications should be given on an ongoing basis to the stakeholders and local communities who have the potential of superior products based on geographical indications; second, it needs a 'political will' of the local government to help the moves of 'institution' as the responsibility of local communities prosper and increase the income of the people, especially farmers in the area; and third, it takes the cooperation and coordination among the 'institutions' and stakeholders in the region in order to provide adequate protection against a potentially superior product geographical indication.

\section{Bibliography}

Bannette, Jennifer. "Geographical Indication as a Tool to Promote Suistainability? Café de Colombia and Tequila Compared". Ecolo- gy Law Quartely, Vol. 39 2012. University of California-Berkeley School of Law;

Bowen, Sarah. "Embedding Local Places in Global Spaces: Geographical Indications as a Territorial Development Strategy". Rural Sociology, Vol. 75 No. 2 June 2010. New York: Cornell University;

Bowen, Sarah and Ana Valenzuala Zapata. "Geographical Indications, Terroir, and Socioeconomic and Ecological Sustainability: The Case of Tequila". Journal of Rural Studies, Vol. 25 2009. United Kingdom: Elsevier Ltd.;

Bramley, Cerkia Kristeen. "The Economics of Geographical Indications: Toward a Conceptual Framework, Estelle Bienabe, and Johann for Geographical Indication Research in Developing Countries". WIPO Research Papers, Januari 2009;

Caenegem, William Van, Jen A. Cleary, and Peter Drahos. "Pride and Profit: Geographical Indications as Regional Development Tools in Australia". Journal of Economic and Social Policy. Vol. 16 | Iss. 1 Art. 5 2014. Australia: Southern Cross University;

Djulaeka. "Perlindungan Indikasi Geografis dan Peran Serta Pemerintah Daerah". Jurnal Ilmu Pengetahuan Sosial, Vol. IX Maret 2008. Jember: FKIP-Jember University in collaboration with the Association of Graduate IPS East Java;

2014. Konsep Perlindungan Hak Kekayaan Intelektual (Perspektif Kajian Filosofis HaKI Kolektif-Komunal. Malang: Setara Press;

Djulaeka, Yudi Widagdo Harimurti, and Makhmud Zulkifli. "Tantangan Daerah dalam Upaya Perlindungan Indikasi Geografis". SNaPP2014-Proceedings of the Social, Economic and Humanities, Vol. 4 No. October 1, 2014. Bandung: UNISBA.

Edger, Rob. "Collective Rights". Saskatchewan Law Review. Vol. 72 No. 1 2009. Canada: University of Saschatchewan - College of Law;

Efendy, Mahfud, dkk. 2013. Land Suitability Mapping Activity Zone area in Pamekasan Tobacco Plants. Research Report. Unpublish, Bangkalan: Faculty of Agriculture, Trunojoyo University and BAPPEDA Pamekasan;

Fakhry, Moh. et.al. 2007. Permodelan Penyuluhan Dalam Rangka Pemberdayaan dan 
Pelestarian Hak Indikasi Geografis Budaya Tradisional Madura. Reports of Competitive Research Grant. Unpublish. Bangkalan: Trunojoyo University;

Gibbons, Zeynita. "Gayo Coffee is no Longer Trademark Dutch company". July 25th 2013, available on the website: www.antaranews.com/, accessed on March 20, 2015;

Handaka, Tataq dan Surokim. "Communication Patterns as Madura Tobacco Growers Group Policy Formulation Base Political Economic Empowerment". Journal Karsa, Vol. 23 No. December 2, 2014. Pamekasan: STAIN Pamekasan;

Ikhwan, Mufarrijul, Djulaeka, dkk. "The setting of Traditional Knowledge (Traditional Knowledge) Law as Safeguard Local Wisdom by Parliament Bangkalan Madura", Journal Yustisia, Ed. 85 January-April 2013. Surakarta: Faculty of Law, UNS;

J, Anson C. "Geographical Indications: A Marketing Stance". Int'l Journal of Economics, Commerce and Research (IJECR), Vol. 2 Iss. 2 June 2012. USA: Transstellar Journal Publications and Research Consultancy Private Ltd.;

Jay, Tim and Madeline Taylor. "A Case of Champagne: A Study of Geographical Indications". Vol. 29 July 2013. Australia: Faculty of Law - Bond University;

Marette, Stéphan. "Can Foreign Producers Benefit from Geographical Indications under the New European Regulation?" Estey Centre Journal of International Law and Trade Policy, Vol. 10 No. 1 2009. Canada: Estey Centre for Law and Economics in International Trade;

Mcbride, Webster D. "Gi Joe? Coffee, Location, and Regulatory Accountability". New York University Law Review, Vol. 85: 2138 December 2010. New York: New York University School of Law;

Moschini, Giancarlo, Luisa Menapace, and Daniel Pick. "Geographical Indications and the Competitive Provision of Quality In Agricultural Markets". American Journal of Agricultural Economics- Vol. 90 No. 3 August 2008. USA: Agricultural \& Applied Economics Association;

Satriawan, Bondan and Henny Oktavianti. "Poverty Alleviation Efforts at Farmers Using Collective Actions Institutional Model of Agriculture". Journal of Development
Economics, Vol. 13 No. June 1, 2012. Surakarta: Surakarta Muhammadiyah University;

Tregear, Angela, et.al. "Regional Foods and Rural Development: The Role of Product Qualification". Journal of Rural Studies, Vol. 23 2007. United Kingdom: Elsevier Ltd. 